\title{
ОЦЕНКА ОКИСЛЕНОСТИ РАСТИТЕЛЬНОГО МАСЛА МЕТОДОМ МНОГОВОЛНОВОЙ УФ СПЕКТРОФОТОМЕТРИИ
}

\author{
Власова И.В.
}

Омский государственный университет им. Ф.М. Достоевского, Омск, Россия

\author{
vlaso-iri@yandex.ru
}

DOI: 10.26902/ASFE-11_150

Растительные масла широко используются в пищевой промышленности, фитотерапии, фитокосметике, фармацевтике и многих других областях. Поскольку они имеют выраженную биологическую активность, важен контроль их качества. Основная причина ухудшения качества масла - окисление под действием различных факторов остатков полиненасыщенных кислот, поэтому оценке степени окисленности масла уделяется большое внимание. В основе наиболее распространенных методик лежат спектрометрические методы. Они достаточно просты в исполнении, не требуют сложного дорогостоящего оборудования. В литературных источниках часто встречается спектрофотометрическая методика оценки степени окисленности масел, основанная на вычислении отношения оптических плотностей растворов масел при двух длинах волн, 215 нм и 232 нм. Этот показатель называют индексом окисленности липидов [1-3]. Считается, что при 215 нм поглощают только не окисленные формы липидов (жиров), а при 232 нм - только продукты их окисления. Но данный способ не учитывает наблюдаемые отклонения от закона Бера и неселективность светопоглощения на выбранной длине волны, что должно приводить к неточным результатам анализа.

Разработан способ многоволновой оценки окисленности растительных масел. Модельные объекты - разбавленные водно-изопропанольные и гексан-изопропанольные растворы льняного масла. Спектры поглощения исследуемых растворов (или экстрактов) регистрировали в УФ-области (210-250 нм). Содержание исходного (не окисленного) масла и суммарное содержание окисленных структур находили, применяя алгоритм множественной линейной регрессии. Ступенчатым характером окисления пренебрегали. Разработанный метод позволяет правильно определить общую концентрацию масла на уровне 0,01-0,06 мг/мл и оценить массовую долю окисленных структур (степень окисленности) [4]. Предложенный метод использован для изучения динамики пероксидного окисления льняного масла в разных растворителях и разных условиях. В ходе эксперимента варьировали температуру, время экспозиции, начальные концентрации $\mathrm{H}_{2} \mathrm{O}_{2}$ и масла. Показано, что на скорость окисления масла в водно-изопропанольных растворах влияют аскорбиновая кислота, галловая кислота, рутин и другие антиоксиданты. Окисление масла сильно замедляется рутином, в меньшей степени - галловой кислотой. В присутствии аскорбиновой кислоты масло не окисляется; изменения спектра наблюдаются лишь после завершения пероксидного окисления аскорбиновой кислоты.

\section{Список литературы}

1. Волчегорский И.А., Налимов А.Г., Яровинский Б.Г., Лифшиц Р.И. // Журн. Вопросы медицинской химии. 1989. том: 35, № 1. С. 127-131.

2. Рыбакова О.В., Сафонова Е.Ф., Сливкин А.И. // Журн. Вестник ВГУ. 2007. № 2. С. 171-173.

3. ОФС 1.5.2.0002.15 Масла жирные растительные. Государственная фармакопея Российской федерации ХІІІ.

Том 2. М:. ФЭМБ, $2015-1004$ c.

4. Зотова А.А., Власова И.В., Гро Е.П. // Журн. Вестник Омского университета. 2019. Том 24, № 3. С. 69-73. 